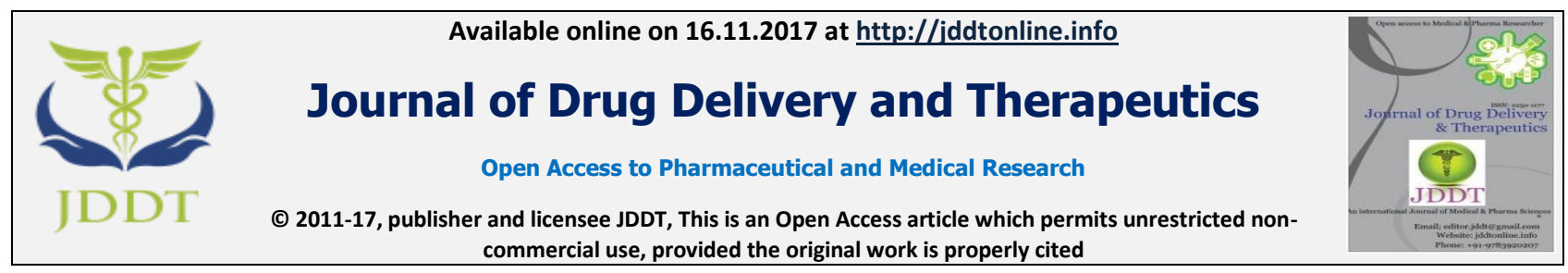

Open 2 Access

Re search Article

\title{
PHYTOCHEMICAL PROFILE OF LEAVES OF AEGLE MARMELOS (Linn.) CORREA
}

\author{
N. B. Khairnar and V. B. Kadam \\ P.G. Department of Botany \& Research Centre, K.T.H.M. College, Nasik, India - 422002
}

\section{ABSTRACT}

Aegle marmelos (Linn) Correa, commonly known as bael or (bel), belonging to the family Rutaceae, is a moderate sized, slender and aromatic tree. A number of chemical constituents and various therapeutic effects of leaves of Aegle marmeloshave been reported by different workers. The leaves of Aegle marmelos contain alkaloids, phenylpropanoids, terpenoids and other miscellaneous compounds whereas the potential pharmacological activity of the leaves are hypoglycemic, anti-inflammatory, antimicrobial, anticancer, radioprotective, chemopreventive and anti-oxidative activity. The continuous two year investigation showed that leaves generally accumulated highest amount of chlorophyll a $(2.60 \mathrm{mg} / \mathrm{g}$ fresh wt.), chlorophyll $\mathrm{b}(1.73 \mathrm{mg} / \mathrm{g}$ fresh wt.) and carotenoid $(1.51 \mathrm{mg} / \mathrm{g}$ fresh wt. ) in summer season compare to monsoon and winter.

Keywords: Chlorophyll a, chlorophyll b, carotenoid and Aegle marmelos

Article Info: Received 13 Oct, 2017; Review Completed 14 Nov, 2017; Accepted 15 Nov, 2017; Available online 15 Nov, 2017

口ite this article as:

Khairnar NB, Kadam VB, Phytochemical profile of leaves of aegle marmelos (linn.) correa, Journal of Drug Delivery and Therapeutics. 2017; 7(6):88-90

DOI: http://dx.doi.org/10.22270/jddt.v7i6.1533

*Address for Correspondence

N. B. Khairnar, P.G. Department of Botany \& Research Centre, K.T.H.M. College, Nasik, India - 422002

E-mail: drvbkadam@yahoo.com

\section{INTRODUCTION}

Medicinal plants are having richest resource of medicinal properties and drugs. Number of medicinal systems is directly or indirectly dependent on plants neutraceuticals, food supplements and folk medicines, traditional systems of medicine, modern medicines, and pharmaceutical intermediates ${ }^{1}$. (Hammer et.al, 1999). Medicinal plants are used for the treatment of many diseases. In nature a number of medicinal plants are naturally grown and has relied on the vast variety of natural chemistries found in plants for their biochemical and therapeutic properties ${ }^{2-4}$ (Seyyed, et.al, 2010; Gaykhe and Kadam, 2017). Medicinal plants are not having the pharmaceutical approach, but there is a wider and diverse tendency to utilize herbal plant product to supplement the food, diet, and its main intense is to improving the quality of human as well as animal life and preventing the number of diseases ${ }^{4,5}$ (Kadam et.al.,2017, Maffei, 2003;).
Aegle marmelos (Linn) Correa, commonly known as bael (or bel), belonging to the family Rutaceae, is a moderate-sized, slender and aromatic tree. It is indigenous to India and is abundantly found in the Himalayan tract, Bengal, Central and South India. It is extensively planted near Hindu temples for its wood and leaves which are generally used for worship. Its branches are armed with sharp straight spines. The bark is soft, light grey and exfoliating in irregular flakes. The bright green leaves are alternate and trifoliolate (rarely five-foliolate). The flowers are greenish white and sweet-scented. Fruits are yellowish grey and globose with woody rind and seeds are numerous, oblong and compressed. The roots are fairly large, woody and often curved $^{6,7}$ (Chopra, 1956; Kirtikar and Basu, 1980). Fresh leaf juice is used in asthmatic complaints and jaundice. The Chinese used the leaves and young fruits to adulterate Opium. In Bengal it is used for dysentery. In Konkan, small and unripe fruits are used for piles. 
The juice of bark is a remedy for poverty of seminal fluid $^{7}$ (Kirtikar and Basu, 1980).

The plant has been used in the Indian traditional medicines from time immemorial. It is associated with various important medicinal properties. Chemical investigation on the different parts of the plant has resulted in the isolation of a large number of novel and interesting metabolites. Some of the compounds have been screened for bioactivity. The leaves of Aegle marmelos are made into poultice, used in the treatment of ophthalmia, and the free ash juice is praised in catarrhs and feverishness. In external inflammations, the juice of the leaves is given internally to remove the supposed derangement of tumours ${ }^{7}$ (Kirtikar and Basu, 1980). Arul et al., 2005, studied that the leaves of Aegle marmelos possess the anti-inflammatory, antipyretic and analgesic properties ${ }^{8}$.

\section{MATERIALS AND METHODS}

The amount of Chlorophyll a, Chlorophyll b, and Carotenoid were calculated by the methods of Duxbury and Yestsch ${ }^{9}, 1956$ and Maclachalam ${ }^{10}$ and Zalik, 1963. The pigments of Chlorophyll a, Chlorophyll b, and Carotenoids were extracted from leaf by using $80 \%$ acetone. The different optical densities were recorded at 480, 510, 645 and $663 \mathrm{~nm}$ in spectrophotometer.

1) Calculation for Chlorophyll a =

$$
\frac{12.3 \mathrm{D}_{663}-0.86 \mathrm{D}_{645}}{\mathrm{~d} \times 1000 \times \mathrm{W}} \times \mathrm{V}
$$

2) Calculation for Chlorophyll $\mathrm{b}=$

$$
\frac{19.3 \mathrm{D}_{645}-3.6 \mathrm{D}_{663}}{\mathrm{~d} \times 1000 \times \mathrm{W}} \times \mathrm{V}
$$

3) Calculation for Carotenoids=

$$
\frac{7.6 \mathrm{D}_{480}-1.49 \mathrm{D}_{510}}{\mathrm{~d} \times 1000 \times \mathrm{W}} \times \mathrm{V}
$$

Where as

' $\mathrm{d}$ ' is the length (cm) of light path, ' $\mathrm{V}$ ' is the volume of the chlorophyll solution and ' $\mathrm{W}$ ' is the fresh weight of leaves of Aegle marmelos.

\section{RESULTS AND DISCUSSION}

Chlorophyll is the green pigment present in plant plays vital role in photosynthesis which absorbs light from sun and uses its energy to synthesize carbohydrates from $\mathrm{CO}_{2}$ and water. Carotene function as accessory pigments in plants, helping to fuel photosynthesis by gathering wavelengths of light not readily absorb by chlorophyll. They have been shown to act as antioxidants and to promote healthy eye sight in humans.

The chlorophyll a, content of leaves was raised in summer $(2.60 \mathrm{mg} / \mathrm{g}$ fresh wt.) over that of monsoon ( $1.79 \mathrm{mg} / \mathrm{g}$ fresh wt.) and winter $(1.84 \mathrm{mg} / \mathrm{g}$ fresh wt.). The chlorophyll b, content of leaves was higher in summer $(1.73 \mathrm{mg} / \mathrm{g}$ fresh wt.) over that of monsoon ( $1.25 \mathrm{mg} / \mathrm{g}$ fresh wt.) and winter $(1.53 \mathrm{mg} / \mathrm{g}$ fresh wt.). The carotenoid, content of leaves was accumulated more in summer $(1.51 \mathrm{mg} / \mathrm{g}$ fresh wt.) over that of monsoon ( $1.13 \mathrm{mg} / \mathrm{g}$ fresh wt.) and winter $(1.30 \mathrm{mg} / \mathrm{g}$ fresh wt.). The range of chlorophyll $\mathrm{a}$, chlorophyll $\mathrm{b}$ and carotenoid were found to be in increasing order of monsoon < winter < summer (Table 1 and Graph 1).

Table 1: Estimation of chlorophyll pigment in leaves of Aegle marmelos

\begin{tabular}{|l|l|l|l|}
\hline Season & $\begin{array}{l}\text { Chlorophyll a } \\
(\mathrm{Mg} / \mathrm{g} \text { fresh wt. })\end{array}$ & $\begin{array}{l}\text { Chlorophyll b } \\
(\mathrm{Mg} / \mathrm{g} \text { fresh wt. })\end{array}$ & $\begin{array}{l}\text { Carotenoid } \\
(\mathrm{Mg} / \mathrm{g} \text { fresh wt. })\end{array}$ \\
\hline Summer & 2.60 & 1.72 & 1.51 \\
\hline Monsoon & 1.84 & 1.25 & 1.13 \\
\hline Winter & 1.79 & 1.53 & 1.30 \\
\hline
\end{tabular}

Table 2: Chlorophyll versus season (Analysis of Variance)

\begin{tabular}{|l|l|l|l|l|l|}
\hline Source & DF & Adj SS & Adj MS & F-Value & P-Value \\
\hline Season & 2 & 0.4866 & 0.2433 & 1.39 & 0.320 \\
\hline Error & 6 & 1.0534 & 0.1756 & & \\
\hline Total & 8 & 1.5400 & & & \\
\hline
\end{tabular}

P Value for season is 0.320 and greater than alpha level.

Conclusion: There is no significant difference between chlorophylls among the seasons. 


\section{Graph 1: Estimation of chlorophyll pigment in leaves of Aegle marmelos.}

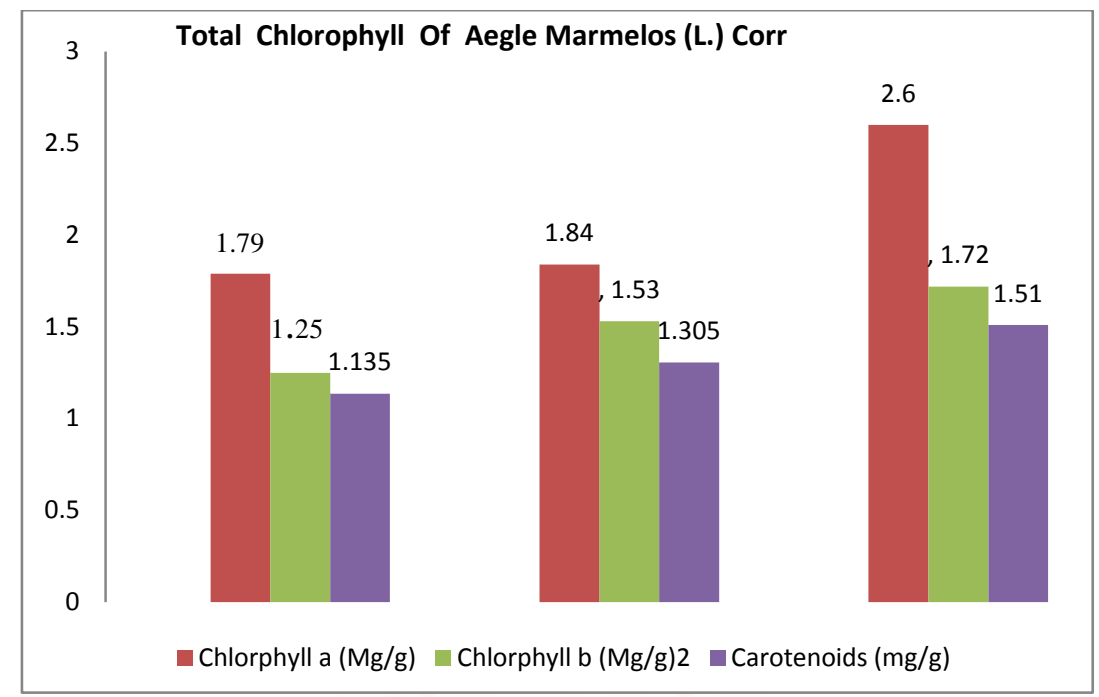

\section{REFERENCES}

1. Hammer K.A, Carson CF, Riley TV, Antimicrobial activity of essential oil and other plant extracts. Journal of Applied Microbiology; 1999; 985-990.

2. Seyyed MS, Masumeh N, Ismaieel D, Hossein M. Antibacterial activity of hydroalcoholic extract of Callistemon citrinus and Albizia lebbeck. American Journal of Applied Sciences 2010; 7:13-16.

3. Gaykhe RC, Kadam Vasant B. "Estimation of pigments content in leaves of Cassia tora Linn"International Journal of Pharmaceutical Research and Bioscience, 2017; 6(4):186-190

4. Kadam Vasant B, Deore Sonali V, Kadam UB, "Estimation of chlorophyll content in leaves of Trigonella foenum-graecum Linn."World Journal of Pharmacy and Pharmaceutical Sciences 2017; 6(3):569-572

5. Maffei, M, Dietary Supplements of Plant Origin: Nutrition and Health Approach. 1st edn. CRC Press, USA, p: 2003, 256.

6. Chopra RN, Nayar SL, Chopra IC, Glossary of Indian Medicinal Plant, C.S.I.R., New Delhi, 8. 1956.

7. Kirtikar KR, Basu BD, Indian Medicinal Plants, 2nd edn. M/s Bishen Sing Mahendra Pal Singh, New Connaught Place, Dehra Dun, 1980; 1:499.

8. Arul V, Miyazaki S, Dhananjayan R, J. Ethnopharmacol. 2005; 96(1-2):159-63

9. Duxbury AC, Yentach CS, Plankton pigment monograph, Marine Res., 1956; 15:190-191

10. Maclachalam S, Zalik S, Plastid structure, chlorophyll concentration and free amino acid composition of a chlorophyll mutant of Barley. Can J. Bot., 1963; 41:10531062. 